Review

\title{
ALBUMEN PROTEIN AND FUNCTIONAL PROPERTIES OF GELATION AND FOAMING
}

\author{
Ana Cláudia Carraro Alleoni \\ R. Athaualpa Vaz de Melo, 179 - 13405-216 - Piracicaba, SP - Brasil. \\ e-mail<anaccarraro@terra.com.br>
}

\begin{abstract}
Hen eggwhite proteins have been extensively utilized as ingredients in food processing because of their unique functional properties, such as gelling and foaming. This work reviews the molecular basis of the eggwhite proteins targeting the development of these functional properties during processing. Key words: ovalbumin, coagulation, gel, denaturation
\end{abstract}

\section{PROTEÍNAS DO ALBUME E PROPRIEDADES FUCIONAIS DE GELATINIZAÇÃO E FORMAÇÃO DE ESPUMA}

\begin{abstract}
RESUMO: As proteínas da clara do ovo de galinha têm sido extensivamente usadas como ingredientes em alimentos processados, devido às suas propriedades funcionais, tais como gelatinização e formação de espuma. Essa revisão aborda as bases moleculares das proteínas da clara do ovo para o desenvolvimento dessas propriedades funcionais durante o processamento.

Palavras-chave: ovalbumina, coagulação, gel, desnaturação
\end{abstract}

\section{INTRODUTION}

Hen eggwhite have been extensively used as processed food ingredients, because of their functional properties of gelation and foam formation, ovalbumin proteins of chicken eggs have been used as processed food ingredients (Mine, 1995). Gelation has evident importance given the amount of available products to consumers, such as desserts, puddings, reformulated meat products, tofu, and surimi. The success of many cooked food is related to protein coagulation, especially the coagulation of egg proteins. Eggwhite and yolk can coagulate and act as linkage with other ingredients (Mine, 1995).

Proteins make gels through ordinate polymerization of molecules, providing a three-dimensional network, and this process occurs by the transformation of the viscous liquid in a viscous-elastic matrix (Hermanssom, 1979). Foam is found in bread, cakes, cookies, meringues, ice creams, and several bakery products. These products depend on air incorporation to maintain their texture and structures during and after processing. The proteins encapsulate and retain air, improving the desirable textural attributes. The ability of protein to form and stabilize foam is related to its amphiphilic behavior (polar/nonpolar) (Du et al., 2002). This study aims to review the molecular bases of ovalbumin proteins and their functional properties of gel and foam formation and stabilization.

\section{ALBUMEN PROTEINS}

The eggwhite has 9.7 to $12 \%$ protein (Vadehra \& Nath, 1973; Mine, 1995) and can be considered a system built out of numerous globular proteins in an aqueous solution. The seven largest fractions are ovalbumins $A_{1}$ and $A_{2}$, ovoglobulins $G_{1}, G_{2}$ and $G_{3}$, ovomucoid and conalbumin. Table 1 presents amounts of several proteins of eggwhite and some of their properties.

\section{Ovalbumin}

Ovalbumin constitutes $54 \%$ of eggwhite's total protein (Zabik, 1992) and is its main protein (Stevens, 1996). Vadehra \& Nath (1973), Osuga \& Feeney (1977), and Zabik (1992) report the existence of three ovalbumin fractions (A1, A2 and A3), detected by electrophoretic techniques. These fractions differ regarding the phosphorus content of their molecules. Ovalbumin $\mathrm{A}_{1}$ has two phosphate groups per molecule, $\mathrm{A}_{2}$ has one group, and $\mathrm{A}_{3}$ has no phosphate group (Vadehra \& Nath, 1973; Zabik, 1992). Ovalbumin is a monomer, globular phospoglycoprotein with molecular weight of $44.5 \mathrm{kDa}$, isoelectric point of 4.5 , and has 385 residues from aminoacids (Nisbet et al., 1981), half of them hydrophobic (Powrie \& Nakai, 1985; Zabik, 1992; Mine, 1995).

Ovalbumin contains $3.5 \%$ carbohydrates and has four free sulphydrilic groups and a disulphide group. It can be denatured by heat exposure, by surface absorption, in films, through agitation, or by the action of several denaturant agents (Vadehra \& Nath, 1973). 
Table 1 - Physical-chemical characteristics of albumen proteins (Source: Powrie \& Nakai, 1985).

\begin{tabular}{lccccc}
\hline Protein & Albumen & IP & Molecular Weight & $\mathrm{T}_{\mathrm{d}}$ & Characteristic \\
\hline & \% dry weight & & $\mathrm{Da}$ & ${ }^{\circ} \mathrm{C}$ & \\
Ovalbumin & 54.0 & 4.5 & 44,500 & 84.0 & Fosfoglicoprotein \\
Conalbumin & 12.0 & 6.1 & 77,700 & 61.0 & Linkage with metal ions \\
Ovomucoid & 11.0 & 4.1 & 28,000 & 77.0 & Inhibitory to trypsin \\
Ovomucin & 3.5 & $4.5-5.0$ & $5.5-8.3 \times 106$ & - & Sialoprotein \\
Lisozime & 3.4 & 10.7 & 14,300 & 75.0 & - \\
Globulin $\mathrm{G}_{2}$ & 4.0 & 5.5 & 49,000 & 92.5 & - \\
Globulin $\mathrm{G}_{3}$ & 4.0 & 5.8 & 49,000 & - & - \\
Avidin & 0.05 & 10.0 & 68,300 & - & Linkage with biotine \\
\hline P - isoet & & & &
\end{tabular}

IP - isoelectric point; $T_{d}-$ denaturation temperature.

During storage, ovalbumin is altered to s-ovalbumin, an extra heat-stable form (denaturation at $92.5^{\circ} \mathrm{C}$ ) in comparison to ovalbumin (denaturation at $84.0^{\circ} \mathrm{C}$ ), as determined by thermogram of the differential scanning calorimeter (DSC) (Donovan \& Mapes, 1976). S-ovalbumin has a slightly lighter molecular weight than ovalbumin and its relative quantity in the eggwhite can increase during the storage period, from $5 \%$ in fresh eggs to $81 \%$ after six months of refrigerated storage. Both $\mathrm{pH}$ and temperature also affect the s-albumin formation (Vadehra \& Nath, 1973). The sovalbumin dependency on $\mathrm{pH}$ indicates a step of initial ionization involving a sulphydrilic group and an amino group, or even the dependency on the concentration of hydroxyl ion, similar to an alkaline hydrolysis (Smith \& Back, 1965). The conversion of ovalbumin to the extra stable form s-ovalbumin results from differences in the structure of covalent bonding (Zabik, 1992). When eggs are covered with oil, coated with whey concentrate protein (Alleoni \& Antunes, 2004), or stored under refrigeration, this conversion is delayed as a result of the lower carbon dioxide loss by the pores of the egg shell.

Alleoni (1997) evaluated effects of storage periods and two temperatures on poultry eggs. S-ovalbumin contents registered were 18, 26 and $24 \%$ in eggs stored at $8^{\circ} \mathrm{C}$ for 7,14 and 21 days, respectively. When stored at $25^{\circ} \mathrm{C}$, eggs presented 56 and $69 \%$ s-ovalbumin at 7 and 14 days, respectively. Smith \& Back (1965) showed that $95 \%$ of ovalbumin is converted to s-ovalbumin when an ovalbumin solution at $\mathrm{pH} 10$ is kept and $55^{\circ} \mathrm{C}$ for $20 \mathrm{~h}$. The maximum production of s-ovalbumin occurs at $\mathrm{pH} 9.2$ and the minimum at $\mathrm{pH} 7.9$, both at $20^{\circ} \mathrm{C}$ (Nguyen \& Smith, 1984). These refereed differences do not provide full explanation regarding the properties of sovalbumin, but properly exemplifies how little changes in a given protein can significantly affect its properties.

\section{Conalbumin or Ovotransferin}

Conalbumin or ovotransferin is glycoprotein that represents $13 \%$ of eggwhite; its molecular weight varies from 60 to $95 \mathrm{kDa}$, with isoelectric point between 6.0 and 6.6 (Vadhera \& Nath, 1973). Conalbumin can bind to metal ions and form a protein-metal complex resistant to denaturation by heat, pressure, proteolitic enzymes, and denaturant agents (Azary \& Feeney, 1958). This protein is complexed with two mols of metallic ion per molecule with relative stability, and its ability to bound to $\mathrm{Fe}$ is related to its antimicrobial activity. Conalbumin has about 15 disulphide bindings and about $55 \%$ reactive residues (Zabik, 1992).

\section{Ovomucoid}

Ovomucoid is a glycoprotein bearing from 20 to $25 \%$ carbohydrates (Osuga \& Feeney, 1977). It is resistant to heat denaturation in acid solutions, and present inhibitory activity to trypsin (Stadelman \& Coterril, 1973). Osuga \& Feeney (1977) observed that ovomucoid from poultry eggs inhibits the bovine trypsin but not the human trypsin. Ovomucoid's molecular weight varies from 26,100 to $28,300 \mathrm{Da}$, and its isoelectric point lies between 3.9 and 4.3 (Vadehra $\&$ Nath, 1973). This protein is stabilized by hydrophobic strengths and its high resistance to heat results from its high cystine contents and, consequently, to the high number of disulphide linkages - eight (Vadehra \& Nath, 1973).

\section{Ovomucin}

Ovomucin is a glycosulphiprotein that contributes to the gel-like structure of the eggwhite thick layer. The eggwhite has two forms of ovomucin; the insoluble form characterizes the high viscosity of eggwhite's thin layer (Hayakawa \& Sato, 1977). Ovomucin presents from one to $2 \%$ of eggwhite's total proteins (Vadehra \& Nath, 1973), and differs from other proteins because its molecule is extremely large and 
contains sulphate esthers, large amounts of cystine (interconnected through intermolecular linkages), and $50 \%$ of the total eggwhite sialic acid contents (Stadelman \& Coterril, 1973). Ovomucin's molecular weight varies from 5.5 to $8.3 \mathrm{MDa}$. Ovomucin also has a substantial amount of disulphide groups, and up to $33 \%$ carbohydrates (Vadehra \& Nath, 1973).

\section{Lysozyme}

Lysozyme is a glycoprotein, a single polypeptide chain with 129 residues of aminoacids linked by four disulphide bonds, representing $3.5 \%$ of the eggwhite; its molecular weight ranges from 14,300 to $14,600 \mathrm{Da}$, and its isoelectric point is 10.7 (Stadelman \& Coterril, 1973). Lysozyme was previously placed in the ovoglobulin group and referred to as $\mathrm{G}_{1}$. Lysozyme's acid and basic lateral chains and terminal groups are distributed in the molecular surface. The localization of polar chain also seems to be in the surface, although most non-polar chains (hydrophobic) are inside the molecule. One of the hydrophobic groups is localized in the protein's surface, exactly where the protein's active site of is located (Li-Chan \& Nakai, 1989).

\section{Ovoglobulins $G_{2}$ and $G_{3}$}

Ovoglobulins encompass altogether $0.4 \%$ of the total eggwhite's proteins. Their molecular weights range from 30,000 to $45,000 \mathrm{Da}$, and their isoelectric points are 5.5 and 5.8 for $\mathrm{G}_{2}$ and $\mathrm{G}_{3}$, respectively. Ovoglobulins have 3.2 to $3.7 \%$ hexoses and 2.4 to $2.5 \%$ hexosamines (Vadehra \& Nath, 1973).

\section{FUNCTIONAL PROPERTIES OF GELATION AND FOAMING}

Proteins present physical-chemical functional properties that contribute to the desirable characteristics of a food and its physical behavior during preparation, transformation and storage. Many functional properties depend on the exposition of hydrophobic groups in the molecular surface and the interactions of these groups with oil (emulsion), air (foam) or other protein molecules, such as gels and coagula (Li-Chan \& Nakai, 1989).

Considering that the residues of hydrophobic aminoacids are generally located inside globular proteins molecules, the unfolding of the native structure during the processing steps of food, such as homogenization, liquidification or heating, can be necessary to allow these hydrophobic groups to participate in the intermolecular interactions (Kato et al., 1989; Li-Chan \& Nakai, 1991). The molecular flexibility of a protein can be constrained by strength of hydrophobic and internal electrostatic interactions that keep the native structure, as well by the presence of covalent disulphide intra-molecular bonds (Mine, 1995).

\section{Gelation}

Gel is an intermediary form between solid and liquid. It is the cross-linking among polymeric molecules which make an intermolecular network within a liquid medium. In food systems, this liquid is water, a solvent which affects the nature and the magnitude of intermolecular strengths that keep the integrity of the polymeric network. This network retains water, avoiding losses (Oakenfull, 1987). Food processing and the development of new products require ingredients such as the gelling agents, which build up a structural matrix that supplies food's desirable texture (Phillips et al., 1994).

Gels can be described by their capacity to immobilize liquids, by their macromolecular structure, by their texture, and by their rheological properties (Phillips et al., 1994). Gel formed from protein was primarily described as a two-step process:

1. The first step involves changes in the conformation (usually induced by heat) or partial denaturation of the protein molecule. With denaturation, the dispersion velocity increases as a result of increasing molecular dimensions caused by unfolding of the protein molecule (Ferry, 1948). In this protein dispersion, the first features of an elastic solid appear.

2. In the second step, a gradual association or molecule aggregations of denatured proteins leads to an exponential increase of viscosity, and to the formation of a continuous network. Process formation in this step is slower, in comparison to the first step, and ends when an organized network is formed. If the $2^{\text {nd }}$ step occurred any faster, a disorganized protein cluster (a coagulum) would be formed; this coagulum would not be able to hold water, consequently resulting in syneresis (Phillips et al., 1994).

The establishment of gel networks at 85 to $90^{\circ} \mathrm{C}$ is attributed to the formation of covalent linkages, to the changes of thiol group to disulphide linkages, and to hydrophobic interactions (Phillips et al., 1994). These interactions between nonpolar segments of adjacent polypeptides occur only if these polypeptides are opened, induced by heating. Cooling increases the hydrogen bonds. The change reaction from thiol group to disulphide linkage is important for thermal gelation, given that it produces crossed covalent linkages involving and stabilizing the gel matrix. The elasticity property of gel is directly proportional to the density of cross-linking in the network (Phillips et al., 1994).

The first step of thermal coagulation comprises the formation of disulphide linkages which exposes hydrophobic groups (Shimada \& Matsuhita, 1980). During heating, eggwhite is polymerized by intermolecular exchange linkages from sulphydrilic groups to 
disulphide linkages, which makes a network. Thermocoagulation requires balance of electrostatic attractions between protein molecules and hydrophobic interactions during the gel formation (Ma \& Holme, 1982).

The physical integrity of gels depends on the balance between attractive and repulsive strengths of the protein molecules involved in the system (Hermanssom, 1979; Schmidt, 1981; Kinsella, 1984; Mulvihill \& Kinsella, 1987; Ziegler \& Foegeding, 1990). If the attractive strengths predominate, a coagulum is formed, and water is driven off the network matrix. If the repulsive strengths dominate, a three-dimensional network can not be formed (Kinsella, 1984).

The nature and properties of gels are influenced by several factors, such as protein concentration, solution $\mathrm{pH}$, nature, and concentration of the electrolyte (Mulvihill \& Kinsella, 1988). Gelation can occur during heating or cooling and depends on the nature of the protein and on the process itself. The heat-induced formation of translucent gel network involves the ordinate association of unfolded chains of polypeptides through non-covalent bonds (e.g. hydrogen bounds, ionic and hydrophobic interactions) and in some cases, through covalent bonds (disulphide linkages) (Hermanssom, 1979; Xiong \& Kinsella, 1990).

The protein-protein, non-covalent interactions occur during the formation of reversible and non-reversible gels. The crossed intermolecular linkages between developed chains of polypeptides vary extensively and are essential to gel formation (Phillips et al., 1994). The kind and the extension of non-covalent interactions, such as hydrophobic and 'Van der Waals' interactions, hydrogen bounds and ionic interactions, are related to the nature of the protein, to its concentration, to the solution $\mathrm{pH}$, to the denaturation intensity caused by heating and by the ionic medium (Schmidt, 1981), and interfere with the attractive and repulsive strengths of the three-dimensional network. Therefore, excess attractive strength cause coagulation, and excess repulsive strength causes dissolution of the network's structure.

Montejano et al. (1984) reported that the rigidity of the eggwhite started at $71^{\circ} \mathrm{C}$ and increased at $83^{\circ} \mathrm{C}$, and the elasticity developed between 70 and $74^{\circ} \mathrm{C}$. Denaturation of ovalbumin occurred from $79^{\circ}$ to $84^{\circ} \mathrm{C}$. The increase of temperature and the heating period improve the linkages with water molecules and increases cross-linking in the gel structure (Yang \& Baldwin, 1995).

The stability of s-ovalbumin regarding the denaturation by heating can affect the gelation properties of eggwhite. Shitamori et al. (1984) reported that even though the profiles of $\mathrm{pH}$ in gel formation have been similar to ovalbumin and to s-ovalbumin, the resistance of heat-induced s-ovalbumin gel was lower than the resistance of ovalbumin gel at several temperatures.

Alleoni \& Antunes (2005) registered higher hardness in eggwhite gels when $\mathrm{pH}$ varied from 9.0 to 9.45 than when $\mathrm{pH}$ varied from 7.7 and 8.1. The sovalbumin can, along with other proteins, increase hardness of albumen gel, i.e., when $\mathrm{pH}$ is around 9.0 there is an increase in the percentage of this protein in the eggwhite, while there is a minimum transformation from ovalbumin to s-ovalbumin when $\mathrm{pH}$ ranges from 7.0 to 8.0. In the literature, there is no indication regarding an increase of other kinds of proteins with increasing $\mathrm{pH}$.

The success of egg cooking depends on time and temperature. The exposition to very high temperatures for an extended period results in a supercoagulation. Good results can be obtained with high temperatures if the cooking period is properly shorter. Heating is needed to achieve the optimum hardness, but can also bring on undesirable syneresis (Lowe, 1955). The syneresis registered by Chen \& Hsu (1981) may have resulted from supercoagulation, when the whole egg and the eggwhite were cooked in microwaves, but the cooking velocity induced by the microwaves and the tendency of how heating is carried out harden the supercoagulation prevention in some foods (Yang \& Baldwin, 1995). Alleoni \& Antunes (2005) observed increased expressible moisture in eggwhite gels at $\mathrm{pH}$ between 7 and 8 , in comparison to those with $\mathrm{pH}$ around 9 .

When puddings are cooked at high temperatures, there is little difference between the optimum thicken and the breakdown of the product. When cooking is proceeded in water bath, the optimum temperature is $87^{\circ} \mathrm{C}$, and the denaturation temperature is $92^{\circ} \mathrm{C}$ (Yang \& Baldwin, 1995). Differences in gelforming ability among globular proteins generally reflect the variety of degrees of protein-protein interactions and the number and extension of interactive sites available within the opened molecule (Phillips et al., 1994).

The intermolecular disulphide linkages increase the stability of the gel matrix. The increased size of polypeptide chains can delay the rupture of non-covalent interactions, and favor the gel network stability. The inaccessible thiol groups become exposed and can be activated by the unfolding of protein molecule during heating, or by alterations in the solvent conditions (Kella \& Kinsella, 1988). Consequently, the reactive thiol groups are exposed and can yield intermolecular disulphide bond (Schmidt et al., 1979). The reactions of intermolecular changes of thiol-disulphide 
groups can promote an increase of crossed disulphide linkages within the gel matrix, according to the reaction scheme.

$-\mathrm{S}-\mathrm{S}-\mathrm{S} * \mathrm{H}-+-\mathrm{S} * \mathrm{H}-\mathrm{S}-\mathrm{S}-\leftrightarrow \mathrm{HS}-\mathrm{S}-\mathrm{S}-\mathrm{S}-\mathrm{S}-\mathrm{SH}$

The dimerous molecule formed by this reaction can keep on reacting with sulphydrylic groups in other protein molecules, producing the necessary crosslinking to gelation (Phillips et al., 1994). Although the formation of a protein network is described by two steps (Shimada \& Matsushita, 1980), the presence of soluble aggregates that precedes the network formation has been already reported to several proteins (Ma \& Holme, 1982; Nakamura et al., 1984). In addition to these steps, a third one has been proposed, involving denaturation followed by soluble aggregation and by interaction of aggregates within the network, evidences supported by electronic microscopy (Beveridge et al., 1980).

Ferry (1948) introduced the concept that gelation occurs in two steps; he emphasized the importance of the relation between denaturation and aggregation. If the attractive strengths are broken by denaturation, this should quickly promote the chain association. This would result in accumulation of free denatured proteins, as an intermediary phase. In these conditions, a thin layer of gel should be formed. A rough gel should be formed when increasing attractive strengths lead to gelation before the accumulation of many free chains. With increasing attractive strengths, only aggregates should be formed. The relationship between denaturation and association affects the kind of formed network in either mechanism: two steps or one of three steps (Oakenfull, 1987). The coagulation reaction in endothermic, i.e., absorbs heat. Therefore, the velocity of this reaction is affected by temperature.

Feeney (1964) listed proteins according to the percentage existent on the solid albumen: ovalbumin $54 \%$; conalbumin $13 \%$; ovomucoid $11 \%$; lysozyme $3.5 \%$; ovomucin $1.5 \%$; flavoprotein-apoprotein $0.8 \%$; proteinase inhibitor $0.1 \%$; avidin $0.05 \%$, and non-identified proteins $8 \%$. Only ovomucoid and ovomucin are not coagulable by heat (Johnson \& Zabik, 1981); except when complexed with $\mathrm{Fe}$ or $\mathrm{Al}$, conalbumin is especially sensitive to heat (Cunningham \& Lineweaver, 1965). The denaturation temperatures of conalbumin, globulin, ovalbumin and lysozyme are 57.3, 72.0, 71.5, and $81.5^{\circ} \mathrm{C}$, respectively (Yang \& Baldwin, 1995).

\section{Foaming}

There are two main foam classes: the spherical and the polyedric foams. Protein-based foams are formed by air bubbles. Each droplet is involved by a thin and continuous film of protein molecules and each bubble is separated by a lamella. Air bubbles are originally spherical (high internal pressure), and the lamella is dense (thick), containing large amounts of fluid. Liquid in the polyedric foam is distributed among lamellar channels where the films are located. The drainage of lamellar fluids is the main destabilization strength, causing air bubbles to get closer and take on polyedric shape (Adamson, 1982).

During the formation of protein-based foam, a sequence of reactions occurs. An energy input if required for triggering the process, and the soluble proteins reach the air-water interface by diffusion, adsorption, concentration and critical surface tension (Phillips, 1981; German \& Phillips, 1989). The rearrangement of polypeptides occurs in the interface and is oriented by polar mobility, which is directed to water, and the nonpolar segments preferably lead to air particles. This process occurs through the non-covalent interactions of the polypeptides, and is the base of a cohesive, continuous film (Phillips, 1981). The structural components and the attractive electrostatic interactions (strengths) that enable intermolecular associations improve foaming properties; exceedingly repulsive electrostatic interactions lessen foaming ability. The extension of molecular interactions of proteins in the air-water interface and the properties of the interfacial film depend on the kind of protein and the dominant conditions of the solution, which determine foam formation and stabilization (Phillips et al., 1994).

The foaming properties of proteins are fundamentally related to their properties of forming films in the air-water interface. Proteins that can be opened and quickly adsorbed present better foaming properties than those slowly adsorbed and whose structures are more difficult to be opened in the interface. The same strengths that determine the structure and flexibility of a protein, such as the electrostatic and hydrophobic interactions, and the disulphide linkages also determine the interfacial behavior and the protein properties (Phillips et al., 1994).

During the interfacial movement, the partiallyopened proteins form new intermolecular associations with neighboring molecules and form cohesive films, essential to foam formation (Kinsella \& Phillips, 1989). In homogenous systems, the main attractive strengths are hydrogen bounds, hydrophobic interactions, electrostatic and van der Waals forces (Kinsella, 1984). The strength magnitude, which keeps the native protein structure either in solution or at the interface, is important in the foaming properties (Adamson, 1982).

Barmore (1934) apud Halling (1981), showed the stability decrease of foam in the super-beating of the eggwhite, and the drainage increase correlated to the decrease of viscosity of the liquid drained off. 
These changes in viscosity proved to be an important feature of the super-beating. The viscosity decrease does not sufficiently explain the increase in the drainage rate in long periods of eggwhite beating. Conceivably a specific protein component also performs an important role in the eggwhite super-beating (Halling, 1981).

The forces that act in the different stages of foam stability are:

1. Attractive electrostatic force: essential to the protein network formation and film cohesion, in excess may cause coagulation of polypeptides. On the other hand, the role of electronegativity in foam stabilization has been attributed to the electrostatic repulsion in adjacent films. Important features to the formation of optimum films in a simple system can delay the film formation and cause foam destabilization. For instance, some rheological properties that improve film stability are maximized in the isoelectric point range for many proteins; at this point solubility tends to a minimum. To determine foaming properties of a protein, it is necessary to know the balance between hydrophobic and ionic components, although the precise location of these components in three-dimensional molecular form is unknown (Phillips et al., 1994).

2. The nonpolar residues intensively contribute to the interactive forces at the hydrophobic interface. So, they increase the surface activity in which the hydrophilic residues are associated to the decreasing surface activity, and can thus improve the film quality and the foam stability (Nakai \& Li-Chan, 1985). The foam stability depends on the ability of surface activities of proteins improving the film elasticity. Stability can also reflect the balance between forces inside the film and the forces among adjacent bubbles (Kinsella \& Philips, 1989).

The formation process is related to the mixing velocity, the beater geometry and the surface properties of the material to be foamed (Phillips et al., 1990). The maximum levels of air incorporation during the beating reflect in a better actual dynamic equilibrium between mechanical strength and the bubble destruction. This provides an actual measure of foam stability. The foam stability is measured by the time required by a certain amount of liquid to be drained from the foam. The extension of protein film formation is related to the ability of the protein to diminish the surface tension between the air droplet and the protein solution. The foam stability depends on the film nature, which reflects the extension of interactions within the film matrix (Phillips et al., 1994).

The structural characteristics of proteins leading to fast foam formation are low molecular weight and amphipathic molecules. To form a protein capsule that can hold an air bubble, the protein components should present non-covalent interactions, such as electrostatic and hydrophobic strengths, hydrogen bounds and disulphide linkages. The molecular features inherent to proteins affect the formation and stability of protein-based foam (Kinsella \& Phillips, 1989). The critical balance of non-covalent interactions leads to the formation of a cohesive and viscous film, required to stabilize the foam.

The electrostatic repulsion can reduce foam stability and delay the film formation. Disulphide linkages reduce the protein flexibility. The change of a thiol group to a disulphide has great importance to functional properties. Molecular alterations induced by reduction of disulphide linkages among protein molecules improve the film formation in the foam and its stabilization (German \& Phillips, 1989).

The formation of disulphide linkages during the foam formation and the foaming properties of ovalbumin were studied by Doi et al. (1989), who concluded that the essential factor to a stable foam formation of ovalbumin was not the disulphide linkages formation, but the network formation by other non-covalent interactions. The critical role of disulphide binding is stabilizing the protein structure, constraining the molecular unfolding and preventing the total exposition of hydrophobic regions (Li-Chan \& Nakai, 1991). The formation of disulphide bindings at the air-water interface can improve foam stability. The protein concentration, the film thickness, the ionic strength, $\mathrm{pH}$, temperature, and the presence of other components in the food systems, in addition to physical-chemical properties of proteins, affect foaming properties. For instance, the increase of the protein concentration generally causes the formation of a thick lamellar film, which yields more stable foam (Phillips et al., 1994).

Meringues and eggwhite cakes can be made out of ovomucins and ovoglobulins alone. However, when the ovalbumin is absent, the cake mass collapses after growing during the beating period (Yang \& Baldwin, 1995).

When the ovalbumin is alone in an Angel cake mixture, longer beating period is required for foaming and the end product will have a thick texture (MacDonnel et al., 1955). Eggwhites from which globulin and ovomucin are removed, require longer beating periods, and when these mixtures are used in cakes they cause a volume reduction. If the ovoglobulins are returned in the cake mixture, there is an increase in the volume, but the beating period is still long. When the ovomucin is added replacing ovoglobulin, the beating period is diminished, but the volume of cakes is not improved. When both 
ovoglobulin and ovomucin are added, an increase in the cake quality is observed. The addition of a great amount of ovomucin produces an increase in the velocity of foam formation and excessive coagulation of proteins in the bubble surface, plus reduced elasticity of the film surrounding the bubble. Therefore, the volume of a cake baked from this mixture is smaller. The addition of a larger quantity of ovoglobulin in the eggwhite causes a weak foaming property and increases the cake volume. The stability in these cases is obtained only when the quantity of ovomucin is regular (MacDonnel et al., 1955). Alleoni \& Antunes (2004) observed positive correlation between the content of s-ovalbumin and the volume of drained liquid of the eggwhite foam in hen eggs with or without whey concentrate protein coating. The volume of drained liquid increased and the foam stability decreased with increasing s-ovalbumin contents.

The super-beating of the eggwhite makes the ovomucin insoluble, causing losses in the elasticity of the film involving the bubbles. Each successive beating of the drained foam liquid requires a longer period of beating and yields less stable products (MacDonnel et al., 1955; Cunningham, 1976). Large quantities of ovomucin are removed in the first beating, and the drained liquid that is collected of eggwhite foam is identical to that from fresh eggwhite.

Ovoglobulins contribute to high viscosity and to diminish the drainage of liquids from the foam. They also diminish the surface tensions which are especially helpful in the foam initial stage. The loss of surface tension promotes the formation of small air bubbles and causes a smooth texture. The use of protein mixtures produces a mixture of opposed charges that can improve the stabilization of food foams, since the possible electrostatic interactions that may occur are known.

\section{FINAL REMARKS}

Most globular proteins have their own internal structural disposition, as a result of different covalent and non-covalent bindings between and inside the protein molecule, and also between protein groups and the solvent. Physical-chemical features involved in the technological process such as concentration, drying or dilution are known to induce the denaturation process, and change the tertiary and quaternary structures of a protein. In the food industry, proteins are exposed to processes that include purification, high pressure, and heat, among others. Consequently, positive and negative effects can be observed in the development of textural properties, such as gelation, foam formation, and stability. The thermal behavior of proteins in specific chemical conditions can be evaluated by monitoring the structure-function relations. This could enable maximizing the beneficial and minimizing the negative effects. The s-ovalbumin is a protein with distinct, different ability to form gel and foam. In the case of gels, its presence can diminish the moisture loss, a positive effect; but in the case of foam, this protein diminishes the foam stability, a negative effect.

\section{REFERENCES}

ADAMSON, G.K. Physical chemistry of surface. 4.ed. New York: John Wiley \& Sons, 1982. 664p.

ALLEONI, A.C.C. Efeito da temperatura e do período de armazenamento na qualidade do ovo, nos teores de s-ovalbumina e nas propriedades funcionais das proteínas da clara do ovo. Campinas: UNICAMP/ FEA, 1997. 104p. (Dissertação - Mestrado em Nutrição Aplicada à Tecnologia).

ALLEONI, A.C.C.; ANTUNES, A.J. Albumen foam stability and sovalbumin contents in eggs coated with whey protein concentrate. Revista Brasileira de Ciência Avícola, v.6, p.77-82, 2004.

ALLEONI, A.C.C.; ANTUNES, A.J. Perfil de textura e umidade espremível de géis de clara de ovos cobertos com concentrado protéico de soro de leite. Ciência e Tecnologia de Alimentos, v.25, p.153-157. 2005.

AZARI, P.R.; FEENEY, R.E. Resistence of metal complexes of conalbumin and transferring to proteolysis and to thermal denaturation. Journal of Biological Chemistry, v.232, p.292-302, 1958.

BEVERIDGE, T.; ARNTFIELD, S.; KO, S.; CHUNG, J.K.L. Firmness of heat induced albumen coagulum. Poultry Science, v.59, p.12291236, 1980.

CHEN, T.C.; HSU, S.Y. Quality attributes of whole egg and albumen mixtures cooked by different methods. Journal of Food Science, v.46, p.984-986, 1981.

CUNNINGHAM, F.E. Properties of egg white foam drainage. Poultry Science, v.56, p.1819-1821, 1976.

CUNNINGHAM, F.E.; LINEWEAVER, H. Stabilization of egg-white proteins to pasteurizing temperatures above $60^{\circ} \mathrm{C}$. Food Technology, v.19, p.1142-1447, 1965.

DOI, E.; KITABATAKE, N.; HATTA, H.; KOSEKI, T. Relationship of SH groups to functionality of ovalbumin. In: KINSELLA, J.E.; SOUCIE, W. (Ed.) Food proteins. Champaign: AOCS, 1989. p.252266.

DONOVAN, J.W.; MAPES, C.J. A differential scanning calorimetric study of conversion of ovalbumin to s-ovalbumin. Journal of the Science of Food and Agriculture, v.27, p.197-204, 1976.

DU, L.; PROKOP, A.; TANNER, R.D. Effect of denaturation by preheating on the foam fractionation behavior of ovalbumin. Journal of Colloid and Interface Science, v.248, p.487-492, 2002.

FEENEY, R.E. Egg proteins. In: SCHULTZ, H.W.; ANGLEMIER, A.F. (Ed.) Symposium on foods: proteins and their reactions. Wetsport: AVI Publishing, 1964.

FERRY, J.D. Protein gels. Advances in Protein Chemistry, v.4, p.178, 1948

GERMAN, J.B.; PHILLIPS, L.G. Molecular properties of proteins important in foams. In: KINSELLA, J.E.; SOUCIE, W.G. Food proteins. Champaign: AOCS, 1989. p.132-143.

HALLING, P.J. Protein: stabilized foams and emulsions. Critical Reviews in Food Science and Nutrition, v.15, p.155-203, 1981.

HAYAKAWA, S.; SATO, Y. Physicochemical identity of a-ovomucins or b-ovomucins obtained from the sonicated insoluble and soluble ovomucins. Agricultural and Biological Chemistry, v.41, p.11851191, 1977.

HERMANSSOM, A.M. Aggregation and denaturation involved in gel formation. In: SHERMAN, P. Food texture and rheology. New York: Academic Press, 1979. 265p. 
JOHNSON, T.M.; ZABIK, M.E. Egg albumen proteins interactions in an angel food cake system. Journal of Food Science, v.46, p.20712083, 1981.

KATO, A.; IBRAHIM, H.R.; WATANABE, H.; HONMA, K.; KOBAYASHI, K. New approach to improve the gelling and surface functional properties of dried egg white by heating in dry state. Journal of Agricultural and Food Chemistry, v.37, p.433-437, 1989.

KELLA, N.K.D.; KINSELLA, J.E. Enhance thermodynamic stability of â-lactoglobulin at low pH. Biochemical Journal, v.255, p.113118, 1988.

KINSELLA, J.E. Milk proteins: physicochemical and functional properties. Critical Reviews in Food Science and Nutrition, v.21, p.197-262, 1984.

KINSELLA, J.E.; PHILLIPS, L.G. Structure function relationships in food proteins: films and foaming behavior. In: KINSELLA, J.E.; SOUNCIE, W.G.(Ed.) Food proteins. Champaign: AOCS, 1989. p.52-77.

LI-CHAN, E.; NAKAI, S. Biochemical basis for the properties of egg white. Critical Reviews in Poultry Biology, v.2, p.21-57, 1989.

LI-CHAN, E.; NAKAI, S. Raman spectroscopy study of thermally and/ or dithiothreitol induced gelation of lisozyme. Journal of Agriculture and Food Chemistry, v.39, p.1238-1245, 1991.

LOWE, B. Experimental cookery. 4.ed. New York: John Wiley \& Sons, 1955. $573 \mathrm{p}$

MA, C.Y.; HOLME, J. Effect of chemical modification of some physical properties and heat coagulation of egg albumen. Journal of Food Science, v.47, p.1454-1459, 1982.

MacDONNELL, L.R.; FEENEY, R.E.; HANSON, H.L.; CAMPBELL, A.; SUGIHARA, T.F. The functional properties of the egg white proteins. Food Technology, v.9, p.49-53, 1955.

MINE, Y. Recent advances in the understanding of egg white protein functionally. Trends in Food Science and Technology, v.6, p.225$231,1995$.

MONTEJANO, J.G.; HAMANN, D.D.; LANIER, T.C. Thermally induced gelation of selected comminuted muscle systems-rheological changes during processing, final strengths and microstructure. Journal of Food Science, v.49, p.1496-1501, 1984.

MULVIHILL, D.M.; KINSELLA, J.E. Gelation characteristics of whey proteins and b-lactoglobulin. Food Technology, v.41, p.102-111, 1987.

MULVIHILL, D.M.; KINSELLA, J.E. Gelation of b-lactoglobulin: Effects of sodium chloride and calcium chloride on the rheological and structural properties of gels. Journal of Food Science, v.53, p.231-235, 1988 .

NAKAI, S.; LI-CHAN, E. Structure modification and functionality of whey proteins: quantitative structure-activity relationship approach. Journal of Dairy Science, v.68, p. 2763-2772, 1985.

NAKAMURA, T.; UTSUMI, S.; MORI, T. Network structure formation in thermally induced gelation of glycinin. Journal of Agriculture and Food Chemistry, v.32, p.349-352, 1984.

NGUYEN, T.H.; SMITH, M.B. S-ovalbumin in eggs - a review. CSIRO Food Research Quarterly, v.44, p.44-48, 1984.

NISBET, A.D.; SAUNDRY, R.H.; MOIR, A.J.; FOTHERGILL, L.A.; FOTHERGILL, J.E. The complete amino-acid sequence of hen ovalbumin. European Journal of Biochemistry, v.115, p.335-345, 1981.

OAKENFULL, D. Gelling agents. Critical Reviews in Food Science and Nutrition, v.26, p.1-25, 1987.
OSUGA, D.T.; FEENEY, R.E. Eggs proteins. In: WHITAKER, J.R.; TANNENBAUM, S.R. (ED.) Food proteins. 2.ed. Westport: Avi Publishing, 1977. p.209-266.

PHILLIPS, L.G. Protein conformation at liquid interfaces and its role in stabilizing emulsions and foams. Food Technology, v.35, p.50-51, 1981.

PHILLIPS, L.G.; WHITEHEAD, D.M.; KINSELLA, J.E. Structurefunction properties of food proteins. San Diego: Academic Press, 1994. 271p. (Food Science and Technology International Series).

PHILLIPS, L.G.; GERMAN, J.B.; O’NEILL, T.E.; FOEGEDING, E.A.; HARWALKAR, V.R.; KILARA, A.; LEWIS, B.A.; MANGINO, M.E.; MORR, C.V.; REGENSTEIN, J.M.; SMITH, D.M.; KINSELLA, J.E. Standardized procedure for measuring foaming properties of three proteins, a collaborative study. Journal of Food Science, v.55, p.1441-1444, 1990.

POWRIE, W.D.; NAKAI, S. Characteristics of edible and fluids of animal origin: egg. In: Fennema, O. Food chemistry. New York: Marcel Dekker, 1985. p.829-855.

SCHMIDT, R.H. Gelation and coagulation. In: CHERRY, J.P. (ED.) Protein functionality in foods. Washington: ACS; 1981. p.131-147.

SCHMIDT, R.H.; CORNELL, J.; ILLINGWORTH, B. Multiple regression and response surface analysis of the effects of calcium chloride and cysteine on heat-induced whey protein gelation. Journal of Agriculture and Food Chemistry, v.27, p.529-532, 1979.

SHIMADA, K.; MATSUSHITA, S. Relationship between thermo coagulation of proteins and amino acid compositions. Journal of Agriculture and Food Chemistry, v.28, p.413-417, 1980.

SHITAMORI, S.; KOJIMA, E.; NAKAMURA, R. Changes in heatinduced gelling properties of ovalbumin during its conversion to sovalbumin. Agriculture and Biological Chemistry, v.46, p.1539$1541,1984$.

SMITH, M.B.; BACK, J.F. Studies on ovalbumin: II-The formation and properties of the s-ovalbumin, a more stable form of ovalbumin. Australian Journal of Biological Science, v.18, p.365-377, 1965.

STADELMAN, W.J.; COTTERILL, O.J. Egg science and technology. Westport: Avi Publishing, 1973. 314p.

STEVENS, L. Egg proteins: what are their functions? Science Progress, v.79, p.65-87, 1996.

VADEHRA, D.V.; NATH, K.R. Eggs as a source of protein. Critical Reviews in Food Technology, v.4, p.193-308, 1973

XIONG, Y.L.; KINSELLA, J.E. Evidence of a urea-induced sulfhydryl oxidation reaction in proteins. Agriculture and Biological Chemistry, v.54, p.2157-2159, 1990.

YANG, S.C.; BALDWIN, RE. Functional properties of eggs in foods. In: STADELMAN, W.J.; COTTERILL, O.J. Egg science and technology. 4.ed. Binghamton: Food Products Press; Haworth Press, 1995. p.405-463.

ZABIK, M. Eggs and products. In: BOWERS J. Food theory and applications. 2.ed. New York: Macmillan Publishing Co., 1992. p.359-424.

ZIEGLER, G.R.; FOEGEDING, E.A. The gelation of proteins. Advances in Food Nutrition Research, v.34, p.204-286, 1990.

Received January 05, 2006

Accepted April 28, 2006 